\title{
USP13 wt Allele
}

National Cancer Institute

\section{Source}

National Cancer Institute. USP13 wt Allele. NCI Thesaurus. Code C115005.

Human USP13 wild-type allele is located within 3q26.2-q26.3 and is approximately $137 \mathrm{~kb}$ in length. This allele, which encodes ubiquitin carboxyl-terminal hydrolase 13 protein, plays a role in deubiquitination. 